\title{
Features of labor regulation of transport workers in the context of COVID-19 pandemic
}

\author{
Irina Timonina* \\ Russian University of Transport, 127055 Moscow, Russian Federation
}

\begin{abstract}
The article deals with the issue of legal regulation of labor relations in transport in emergency situations. The author analyzes the current labor legislation that regulates the specifics of regulating the labor of employees of transport organizations; the possibility of concluding and terminating labor contracts in emergency situations, and the specifics of their responsibility. Special attention is given to the specifics of the operation of transport enterprises during the COVID-19 pandemic and in other threatening situations in order to ensure the transport security of Russia. The author notes the actual tasks of transport enterprises in special conditions, justifies the need for special requirements for transport workers, the importance of pre-trip medical examinations.
\end{abstract}

\section{Introduction}

The COVID-19 pandemic has caused serious damage to the global economy as a whole, affecting entire industries, including the transport industry, but the state, in such a difficult situation, has provided significant support to both public and private transport enterprises in order to prevent the failure of transport enterprises.

Such assistance was provided, for instance, to aviation and railway transport enterprises, which lost their profits due to the lack of passenger traffic due to the self-isolation regime and the closure of borders.

It should be noted that the COVID-19 pandemic and the subsequent crisis caused by it have had a significant impact on all spheres of political, economic and social life of society, not only in Russia, but also around the world [1].

During the COVID-19 pandemic in Russia, the entire complex of social and labor relations, including at transport enterprises, was transformed.

This is due to the suspension and restriction of the activities of organizations; the reduction of jobs, the closure of enterprises and the dismissal of employees, especially private transport organizations.

In this period of time, according to Rosstat, the number of registered unemployed in Russia since the beginning of the COVID-19 coronavirus pandemic has increased by 4,321 million people. The unemployment rate at the beginning of the pandemic was $4.7 \%$, and in January the number of unemployed citizens was $24.7 \%$, and the highest growth in the number of registered unemployed was recorded in September-October 2020 [2].

\footnotetext{
* Corresponding author: timonina61@yandex.ru
} 
Due to extraordinary circumstances, employers, including transport organizations, were forced to continue working in completely new conditions.

In transport organizations, the regulation of labor relations, taking into account the specifics of the industry and working conditions, has its own characteristics depending on different types of transport (rail, water, road, air).

Labor legislation establishes requirements that are common to all transport workers, but in addition to general legal norms, the work of transport workers is regulated by special rules, which is primarily due to the specifics of the type of activity, the need to ensure traffic safety and operation of transport [3].

The State sets increased requirements for employees working on vehicles, especially during the epidemic, with regard to the health status of employees, their professional training and labor discipline, since vehicles are considered sources of increased danger.

This is especially true for the safety of passenger and cargo transportation in emergency situations.

The work of all types of transport enterprises (railway, sea, river, air, automobile) has its own peculiarities of legal regulation of labor relations. Therefore, during the COVID-19 pandemic and at the present time, much attention was paid to ensuring transport safety and compliance with the labor rights of employees.

Taking into account the nature of the work, special requirements are imposed on the professional skills of transport workers [4].

It should be noted that the legislation for transport workers establishes not only special requirements, but also restrictions related to the specifics of their activities and depending on the significance of the work performed, especially during the quarantine period associated with the coronavirus pandemic (for example, a ban on holding a strike).

In such conditions, special regulations regulate the specifics of the work of employees engaged in activities directly related to the movement of transport and its maintenance, their work and rest regime, and the procedure for bringing them to disciplinary responsibility.

During the COVID-19 pandemic, the above-mentioned employees were subject to increased requirements necessary for them to perform their work duties in order to operate transport enterprises in the most efficient and safe way.

The labor legislation (Chapter 51) obliges employees whose work is related to the movement of vehicles to undergo mandatory periodic and early medical examinations, if this is required by special working conditions. Such inspections are mandatory for railway transport workers in JSC "Russian Railways" and in other transport industries.

In an emergency situation, first of all, persons with the greatest work experience and relevant professional qualities are involved in order to ensure the safety of passenger and cargo transportation.

\section{Methodology}

The author applies the legal analysis of the official legal documents regulating the labor activity of transport workers.

\section{Results and discussion}

During the quarantine period, as practice has shown, when admitted to work, persons associated with the movement of vehicles were strictly selected, taking into account their professional training, mental health and mandatory examination for stress resistance.

The importance and necessity of such an approach was shown by the practice of the last three months of 2020 and the beginning of 2021. 
In this regard, at transport enterprises, employers have tightened control before going on a flight for employees whose activities are directly related to the movement of vehicles.

At the same time, during the COVID-19 pandemic, special attention was paid, and is being paid now, to the mental health of employees, their examination and admission to driving vehicles.

In order to ensure the safety of transport workers and passengers in Russia, measures were taken to prevent coronavirus: disinfection of rolling stock; compliance with sanitary standards by employees; provision of personal protective equipment, contactless payment for travel, automatic door opening, and others.

It is important that in an emergency situation, at transport enterprises, employers especially carefully monitored the working and rest regime of employees, not only in order to comply with labor legislation, but first of all, in order to ensure transport safety and safe working conditions for employees, i.e. to ensure safety and preserve their health during work.

Therefore, in the future, in a period of difficult conditions and with an increased load on employees, employers of transport enterprises should clearly take into account the length of working time of each employee, which consists of time devoted to the work performed during the run of the transport vehicle; time spent on auxiliary work; periods of simple presence (duty); intermediate periods of rest or break in work, the permissible duration of which is established by the competent authority.

The Labor Code of the Russian Federation establishes the right of the federal executive body, taking into account the opinion of the relevant all-Russian trade union and the AllRussian association of employers, to take into account the peculiarities of work, working hours and rest time of employees of transport enterprises whose work is related to the movement of vehicles in any conditions [5].

Such employees are required to establish a shift working time, since the process of transporting passengers and cargo cannot be suspended for technical and technological reasons.

But employees need a continuous full rest at the end of their shift, in order to comply with transport safety. Such rest is necessary to restore the employee's ability to work and must be provided on time.

Driving vehicles are associated with increased complexity of work, an increase in the load on the employee and the duration of working hours. Therefore, a reduction in the length of rest time is not allowed, except in exceptional cases, but even in these cases it can only be temporary (for example, in the case of a terrorist act, an accident, a vehicle malfunction, an accident, a traffic stop, and other emergency circumstances).

But it should be pointed out that such exceptions are allowed only in the above cases to ensure the smooth operation of the transport enterprise.

In a pandemic, it is mandatory for an employee to undergo a strict pre-trip examination for coronavirus disease. If, during the process of admission to the flight, an employee directly connected with the management of the vehicle refuses to undergo a pre-trip medical examination, which is a mandatory condition for admission to work, this fact is considered a violation of labor discipline and the basis for bringing him to disciplinary responsibility.

The employer has the right to require employees who were on vacation, in self-isolation or in contact with persons with COVID-19 to provide the results of the analysis for the absence of the disease for the safety of the surrounding employees and passengers.

It is clear that the introduction of statutes and regulations on discipline is due to the specifics of the working conditions of transport workers and increased requirements for them. But when regulating the labor relations of employees of transport organizations, there is a differentiation of responsibility due to such specifics [4].

It should be noted that compliance with labor discipline by transport workers and improving the safety of work performed, especially during the COVID-19 pandemic and in 
other emergency situations, is one of the main factors for the safe operation of transport enterprises.

Therefore, transport workers bear special responsibility under the discipline regulations, which provide for their special personal increased responsibility.

But scientists point to the fact that each type of disciplinary responsibility has its own specifics, differing from others in the circle of employees who may be subject to disciplinary responsibility, by the types of disciplinary measures applied, by the bodies that impose disciplinary penalties, by the order and terms of appealing against penalties [6].

V. A. Abalduev quite rightly notes the need to review the conceptual legal principles and traditional institutions, including in the field of labor law, which in recent years has been recognized as the most conservative, although the ideas of creating labor law norms that take into account such situations were discussed in the science of labor law during the economic crisis of 2006-2008.

The author suggests using a universal definition of these situations: '.. high-alert mode, emergency situation or other circumstances of an emergency nature provided for by the legislation of the Russian Federation' [7].

We believe that this proposal is quite logical, reasonable and relevant, especially at the present time, including for specifying the work of transport organizations in emergency situations.

And, of course, in emergency situations, the work of transport companies is not suspended, since the specifics of their work involves the use of different working conditions than at other enterprises.

The experts developed recommendations for the work of transport companies during the pandemic and in other emergency conditions, in which the organization can take advantage of the forced pause associated with a decrease in passenger traffic, and begin to develop and implement tools for analyzing the load of vehicles and public transport routes.

What is very important, these tools will allow you to monitor and make adjustments to the operation of the transport system in real time. But collecting such data will require new digital ticketing systems [8].

As practice shows, during the period of self-isolation and the pandemic, some unscrupulous employers violated the rights of employees, so the problem of protecting the labor rights of employees is still relevant today. The number of court cases has increased significantly over the specified period of time, because employees actively use their right to self-defense of labor rights and interests, and apply to the courts.

Labor legislation also establishes other forms and methods of self-defense of the rights of employees, for example, by notifying the employer or his immediate supervisor or other representative of the employer in writing about the refusal to perform work that directly threatens his life and health.

\section{Conclusion}

Fair consideration of court cases and adjudication of labor disputes contributes to the compliance of employers with labor legislation. Employers should keep this in mind and urgently eliminate the violations committed, without bringing labor conflicts to court.

Summing up, it should be noted that in the conditions of the COVID-19 pandemic and other emergency situations, the actual tasks of the work of transport enterprises remain:

1. Strict compliance by the subjects of the labor contract with labor legislation and internal labor regulations;

2. Improving the safety of vehicle operation and their rational use;

3. Special attention should be paid to improving the working conditions of employees of transport enterprises; 
4. Improving the labor efficiency of employees of transport organizations;

5. Compliance of transport workers with safety regulations and instructions on labor protection by employers, sanitary standards;

6. Regulation of working hours and rest time of employees;

7. Close attention to mandatory and pre-trip medical examinations of employees directly driving vehicles;

8. We believe that in emergency situations, the employer has the right to dismiss employees on its own initiative for a single violation of labor discipline;

9. Employers are obliged to take measures to ensure safe working conditions for their employees, especially during a pandemic, in accordance with the recommendations of the Ministry of Labor and other bodies in order to prevent labor disputes.

\section{References}

1. S.M. Anpilov, A.N. Sorochaykin, Fundamentals of Economics, Management and Law, 2(21), 24 (2020)

2. Rosstat data for 2021. Retrieved from: https://rosstat gov.ru / labor (2021)

3. S.Yu. Golovina, Labor law. Textbook for academic baccalaureate. Legal regulation of labor of transport workers. Moscow: Yurayt Publishing House, (2017)

4. A.I. Zemlin, V.V. Kozlov, Counteraction to terrorism. Organizational and legal support in transport, A textbook for bachelor's, specialist's and master's degrees. Moscow: Yurayt Publishing House (2019)

5. Labor Code of the Russian Federation No. 197-FZ of 30.12.2001 (as amended). No. 1, part 1, Article 3. Article 329, (2002)

6. Zemlin, A. I., Khimich T. M., Filippova M., Rasulov A. B., Gotz,E. V., Zemlina O. M., Matveeva M. A., Pixela A. V., Melnikov, Yu., Duhno N. A., Borisov S. V. Mamonova, M. V., Mel'nikov V. S., Openyshev O. S., Petrov, Y. I., Kharlamova, Yu. a. Transport law, textbook. Ser. 73. Bachelor and specialist (2nd ed., lane and DOP) (2019).

7. V.A. Abalduev, Proceedings of the II International Scientific and Practical Conference (Saratov, July 7, 2020) Saratov: Publishing House of the Saratov State Law Academy, 15 (2020)

8. Digest of the Department of International and Regional Cooperation. 'The transport sector in the context of COVID-19'. Accounts Chamber of the Russian Federation, (2020)

9. P. McGillivary, Marine Technology Society J. 52(5), 44 (2018). https://doi.org/10.4031/MTSJ.52.5.11

10. K.Y. Nikolskaya, S.A. Ivanov, V.A. Golodov, G.D. Asyaev, A.V. Minbaleev, Proceedings of the 2017 International Conference 'Quality Management, Transport and Information Security, Information Technologies', IT\&QM\&IS: 87.

http://doi.org/10.1109/ITMQIS.2017.8085769 (2017) 